\section{Isolation and Identification of Ubiquinone 9 from Cultured Cells of Safflower (Carthamus tinctorius L.)}

\section{Manabu Hagimori, Takashi Matsumoto and Masao NoGUCHI}

\section{Central Research Institute, The Japan Tobacco and Salt Public Corporation, Umegaoka 6-2, Midori-ku, Yokohama 227}

Received November 25, 1977

Ubiquinones which act as the redox carrier in the electron transport system in mitochondria have been recognized in animals, ${ }^{1)}$ plants $^{21}$ and microorganisms. ${ }^{3)}$ It is known to date that seven homologues of ubiquinones which contain from 6 to 12 side chain isoprenoid units occur in nature. In higher plants, ubiquinone 10 is known to be the dominant ubiquinone in most species except for some cases. ${ }^{4}$ In some species of higher plants, ${ }^{2,5,6,8,9)}$ ubiquinone 9 has been recognized chromatographically. However, the isolation and the crystallization of ubiquinone 9 from higher plants was achieved only from barley and its malt products. ${ }^{7}$ As for cultured cells, although ubiquinone 10 was isolated as crystals from cultured cells of tobacco, ${ }^{10}$ ubiquinone 9 has not been isolated yet. While our studying on the chemical constituents of cultured safflower cells, the occurrence of an orange pigment which absorbs UV light in the ethylacetate soluble fraction was fairly noticeable. The isolation and characterization of the pigment revealed it to be ubiquinone 9 and this paper deals with the results. The cells of safflower (Carthamus tinctorius L.) were cultured in 3 liter flasks containing 1 liter of Linsmaier \& Skoog's medium ${ }^{11}$ with $a$ naphthaleneacetic acid $2 \mathrm{mg} /$ liter and sucrose $30 \mathrm{~g} /$ liter for 18 to 22 days at $28^{\circ} \mathrm{C}$ on a rotary shaker. The cultured cells were separated from the broth by filtration and were lyophilized. The dried cells $(470 \mathrm{~g})$ were pul- verized and then soaked in 1 liter of ethylacetate for $2 \mathrm{hr}$. After filtration, the residue was further treated by the same procedure five times. The combined extract was dried up in vacuo at 40 to $50^{\circ} \mathrm{C}$, yielding $16.3 \mathrm{~g}$ of crude extract. This was dissolved in a small amount of a mixture of benzene-chloroform $(1: 1 \mathrm{v} / \mathrm{v})$, and then added onto the top of a silicic acid column $(5.6 \times 18 \mathrm{~cm})$ which was previously equilibrated with the same solvent. The elution was carried out with $500 \mathrm{ml}$ of the solvent and the eluate was collected in $10 \mathrm{ml}$ fractions. The yellow colored fractions which were eluted early and contained the UV light absorbing substance were combined. The combined solution was concentrated in vacuo to dryness, giving $260 \mathrm{mg}$ of an orange oil. This was dissolved in a mixture of hexane-ethylacetate $(7: 1 \mathrm{v} / \mathrm{v})$ and added onto a silicic acid column $(1 \times 22 \mathrm{~cm})$ which was equilibrated with the same solvent. Elution was carried out with $200 \mathrm{ml}$ of the solvent and the eluate was collected in $3 \mathrm{ml}$ fractions. The fractions which contained the UV light absorbing substance were combined and concentrated in vacuo to dryness, giving $36.2 \mathrm{mg}$ of an orange oil. This was dissolved in benzene and added onto a silicic acid column $(0.5 \times 21 \mathrm{~cm})$ equilibrated with benzene. The elution was carried out with benzene and the fractions which contained the UV light absorbing substance were combined and concentrated in racuo, giving $30.5 \mathrm{mg}$ of an orange oil. The final purification was carried out by recrystallization from a mixture of chloroform-methanol. Twice recrystallization gave $19.6 \mathrm{mg}$ of yellow crystals; $m p \quad 44.5 \sim 45.5^{\circ} \mathrm{C}$. In the mass spectrum, the dominant feature was the appearance of an intense peak at m/e 235 and 197, which was considered to be due to the characteristic fragmentation of ubiquinone molecules. ${ }^{12}$ The UV spectrum of the substance exhibited a single absorption peak ( $\lambda_{\max }$, ethanol, $\left.275 \mathrm{~nm}, E_{1 \mathrm{~cm}}^{1 \%} 178\right)$ characteristic to ubiquinones, ${ }^{13)}$ and reduction with sodium boronhydride caused the absorption maximum to shift to $290 \mathrm{~nm}$ (ethanol, $E_{1 \mathrm{~m}}^{\mathrm{l} \%} 52$ ) which is also characteristic to ubiquinones. ${ }^{13\}}$ 
Table I. NMR Spectral Data of THE ISOLATED SUBSTANCE

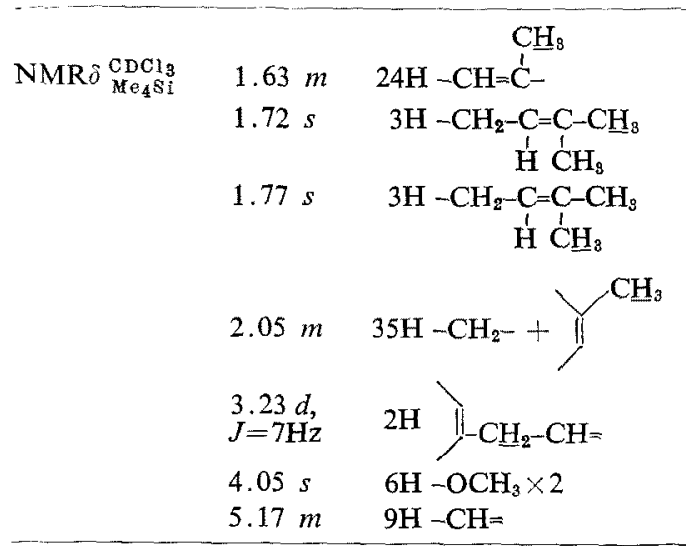

The NMR spectrum (Table I) suggested the presence of a long isoprenoid side chain and methoxy groups but the absence of aromatic ring protons. ${ }^{14}$

These results strongly suggest that the isolated substance is ubiquinone 9. The IR, UV, NMR and mass spectra of the isolated substance were all perfectly identical with those of authentic ubiquinone 9. The behaviors of the isolated substance in the reversed phase thinlayer chromatography for the separation of ubiquinone homologues ${ }^{15}$, were also perfectly identical with those of authentic one.

The mixed melting point of the isolated with authentic ubiquinone $9\left(44.0 \sim 44.5^{\circ} \mathrm{C}\right)$ was $44.0 \sim 45.0^{\circ} \mathrm{C}$, showing no depression.

These results clearly demonstrated that the isolated substance is ubiquinone 9.
Acknowledgement. The authors wish to express their thanks to Drs. T. Fujimori, Y. Takagi and T. Ikeda in our laboratory for their kind suggestions and advices.

\section{REFERENCES}

1) A. T. Diplock and G. A. D. Haslewood, Biochem. J., 104, 1004 (1967).

2) D.R. Threlfall and G.R. Whistance, Phytochemistry, 9, 355 (1970).

3) Y. Yamada, K. Oida and T. Uemura, $J$. Gen. Appl. Microbiol., 15, 181 (1969).

4) F. L. Crane, "Biochemistry of Quinones," ed. by R. A. Morton, Academic Press, London and New York, 1965, pp. 192 193.

5) A. C. Page, Jr., P. H. Gale, F. Koniuszy and K. Folkers, Arch. Biochem. Biophys., 85, 474 (1959).

6) G. S. Hall and D. L. Laidman, Biochem. J., 101, 5P (1966).

7) B. Drews, H. Specht und H.J. Hinze, Naturwissenschaften, 53, 406 (1966).

8) W. T. Griffiths, D. R. Threlfall and T. W. Goodwin, Biochem. J., 103, 589 (1967).

9) A. Law, D. R. Threlfall and G. R. Whistance, Phytochemistry, 9, 2461 (1970).

10) T. Ikeda, T. Matsumoto, K. Kato and M. Noguchi, Agric. Biol. Chem., 38, 2297 (1974).

11) E. M. Linsmaier and F. Skoog, Physiol. Plant., 18, 100 (1965).

12) R. F. Muraca, J. S. Whittick, G. D. Daves, Jr., P. Friis and K. Folkers, J. Am. Chem. Soc., 89, 1505 (1967).

13) R. L. Lester, Y. Hatefi, C. Widmer and F. L. Crane, Biochim. Biophys. Acta, 33, 169 (1959).

14) P. H. Gale, N. R. Trenner, B. H. Arison, A. C. Page, K. Folkers and A. F. Brodie, Biochemistry, 2, 200 (1963).

15) H. Wagner, L. Hörhammer und B. Dengler, $J$. Chromatogr., 7, 211 (1962). 